\title{
Conservation and care: material politics and Atlantic salmon on Newfoundland's Gander River
}

\author{
Jennifer Daniels and Charles Mather ${ }^{*}$ (i)
}

\author{
* Correspondence: \\ cmather@mun.ca \\ Memorial University of \\ Newfoundland, St. John's, Canada
}

\begin{abstract}
This paper aims to contribute to an emerging and vibrant body of post-structural scholarship situated within science technology and society (STS) on practices and their role in world making. Our focus is Atlantic salmon conservation in the Canadian province of Newfoundland and Labrador. We examine the different material and social orders that have over time connected human and salmon bodies. These different socio-material orders do not exist in harmony. On the contrary, they are in tension and reflect different visions/versions of how to conserve and care for Atlantic salmon. Our contribution is to interfere with the dominant narrative of Atlantic salmon conservation by drawing on the concept of care, and by introducing a new salmon that we call the willful salmon.
\end{abstract}

Keywords: Atlantic salmon, Newfoundland, Conservation, Material politics

\section{Introduction}

In March 1992 Canada's Minister of Fisheries and Oceans, John Crosbie, announced the launch of a "programme of conservation and renewal for one of Canada's greatest living treasures, the Atlantic salmon" (Crosbie, 1992, p. 1). Atlantic salmon stocks had been under severe pressure since the 1950s, and this announcement represented a new and urgent effort to conserve this iconic species. The programme involved the retirement of several thousand commercial Atlantic salmon licences in Newfoundland in return for cash payments ranging from CAD $\$ 8000$ to the quite remarkable figure of CAD $\$ 50,000$. Payments to commercial salmon licence holders would be honoured with the return of harvesting gear to the nearest Department of Fisheries and Oceans office (nets, ropes and other equipment necessary to harvest salmon). The retirement offer, the Minister noted, was "the cornerstone of a major program to conserve and enhance Atlantic salmon". Crosbie ended his speech by saying that "today's announcement will help to conserve this matchless game fish for the benefit and pleasure of future generations" (Crosbie, 1992, p. 2, emphasis added).

Crosbie's announcement marked an important milestone in the management of Atlantic salmon in Canada. The 1992 decision effectively closed down an industry that had help sustain coastal communities in Newfoundland for almost 300 years. At the same time, it clearly represented a victory for the increasingly powerful angling

(C) The Author(s). 2017 Open Access This article is distributed under the terms of the Creative Commons Attribution 4.0 International License (http://creativecommons.org/licenses/by/4.0/), which permits unrestricted use, distribution, and reproduction in any medium, provided you give appropriate credit to the original author(s) and the source, provide a link to the Creative Commons license, and indicate if changes were made. 
community, who could now angle for salmon without having to share the resource with commercial harvesters. Yet this was far more than simply shutting down a commercial fishery. The announcement was steeped in material politics: commercial salmon harvesters who agreed to 'retire' their licences in return for cash payments were required to give up their nets, an extraordinary condition that was unprecedented for any other commercial fishery closure in Canada. Our interviews with former fisheries officials revealed that the confiscated nets were subsequently set alight and destroyed. After 1992 nets for salmon were banned altogether: the only legal way to catch salmon in Newfoundland involved the use of a rod, a weighted line and an artificial fly.

The ban on commercial harvesting imposed after 1992 allowed anglers to take a limited number of salmon for personal consumption. Yet since 1992, non-governmental organisations have strongly urged anglers to practice catch-and-release, a method that involves releasing the fish back to the wild after it has been landed. Canada's Department of Fisheries and Oceans (DFO) has fully supported catch-and-release as a conservation method. Indeed, although there are rivers where anglers are permitted to retain Atlantic salmon, catch-and-release has increasingly become a permanent regulation for anglers across Eastern Canada.

Viewed as a material practice that involves the release of salmon for conservation purposes, catch-and-release may seem uncontroversial. Yet from a post-structural sensibility, socio-material practices like catch-and-release are never devoid of politics. Drawing on Donna Haraway's insights, Law and Singleton $(2014,3)$ write that "all practices are material but also semiotically inflicted, performative and political". In other words, socio-material practices are political, and they are also performative in that they generate orders and they enact objects. Law and Mol's (2011) work on foot and mouth disease provides a useful illustration of this (ontological) move. Foot and mouth disease in their work is not a single entity defined through laboratory science. Instead, Law and Mol (2011) argue that the disease is enacted through different material practices associated with the laboratory, the clinic and epidemiology. These different modes of ordering do not provide different perspectives of foot and mouth disease; they are instead different versions of the disease (for a similar move with salmon see Lien and Law, 2011, Lien 2015). Once the different versions are identified, the goal is to "explore the relevant strengths of these worlds, their drawbacks and their limitations" (Law and Mol 2011, p. 2).

For post structural scholars working within the field of science, technology and society (STS) attending to practices like catch-and-release is both a methodological and philosophical project: "Take any practice. Ask about its choreography. Ask how it weaves its relations and enacts its objects" (Law and Lien 2012, 365). Asking about the choreography of a set of socio-material practices requires a very close examination of the materials and methods associated with practices such as catch-and-release. And since socio-material practices vary over time and space, the objects that these practices enact will shift and change.

For Law and Singleton (2014, p. 2), attending to practices is a "toolkit for thinking about and charting the heterogeneous practices of association that make up the social". In this paper we deploy this toolkit to attend to the heterogeneous material practices that are associated with different human salmon entanglements in Newfoundland, and specifically on the Gander River. Our argument is that different modes of ordering 
enact three salmon: the commercial salmon, the catch-and-release salmon and the willful salmon. The first salmon is the commercial salmon and it is part of a heterogeneous network associated with harvesting salmon for commercial gain and personal consumption. Nets as material objects are crucial to this ordering, but there are many other things in this web of relations that enact the commercial salmon. As with all choreographies, they are fragile and subject to failure and dissolution, and by the early 1990s this salmon became extinct. The catch-and-release salmon is enacted through materials associated with recreational fishing: a rod, a reel, weighted line and an artificial fly. This fish is caught for sport and released into the water, with the intent of preserving its life, and the lives of future generations of Atlantic salmon. In Newfoundland, the practices associated with catch-and-release date back to the mid-1940s but they have become more important since the moratorium on commercial salmon. As we show in the paper, catch-and-release methods are promoted alongside salmon conservation, and are juxtaposed to nets and harvesting for commercial gain and personal consumption, practices that are linked to an exploitative past (and an illegal present). In this way catch-and-release, and the fish that it enacts, is performed as a practice that cares for individual Atlantic salmon, and the species as a whole. The third fish is different altogether from the previous two: we call it the willful salmon. In practice, the willful salmon, when caught, is killed and then eaten.

What is the purpose of presenting the material practices that enact different salmon? An emphasis on practices shifts the register on the resource politics of Atlantic salmon. We are no longer asking the question: 'How do we conserve this (singular) species?' We are instead asking which mode of ordering does salmon well?' In asking the question 'which mode of ordering does salmon well', we have found it very productive to engage with a recent interest in STS on the practice and politics of care (Puig de la Bellacasa 2011, 2012; Martin et al., 2015; Mol et al. 2010). In this writing - which brings feminist theory to STS's traditional concerns for a situated and ethical politics care is a relational practice that is situated and contextual. In this sense care is an active practice rather than a moral disposition. What interests us in this writing is the way in which care can be used as an analytic to ask 'what' and 'who' is being cared for in particular socio-material assemblages. At the same time, attending to care should be an unsettling process in that it aims to "foster a politics that might enable better, more livable lives and forms of life" (Martin et al. 2015, 632). In other words, by asking what is being cared for draws "attention to glimpses of alternative, liveable relationalities, and hopefully contributes to other possible worlds in the making" (Puig de la Bellacasa 2015, 692).

We use the concept of care to ask what is cared for, and how does care happen, in the social-material networks that bring humans and salmon together. Shifting the register in this way allows us to interfere with the dominant narrative on the conservation of Atlantic salmon in Canada. This narrative tells us that angling in general, and catchand-release in particular, are crucial for the conservation of Atlantic salmon. By mobilising the concept of care - and by introducing a new salmon 'real' (the willful salmon) - we are able to destabilize this narrative and provide a radically different way of thinking about salmon conservation. In this way our paper responds to Buller's recent call for research that engages with "the contexts and manners in which ethics are formed, performed and reformed through multiple human-animal interactions" (Buller, 2015, 
p. 5; also see Bear and Eden, 2011; Ginn et al., 2014; Keul, 2013; Lorimer, 2006). Our work also hopes to contribute to existing scholarship on Atlantic salmon conservation in the region (Parenteau 1998, 2004), and to broader debates on salmon conservation in a global context (Swanson 2015).

The research methods for this paper involved the collection of archival and published material from Centre for Newfoundland Studies, the Provincial Archives of Newfoundland and Labrador, and electronic databases of historical material held at Memorial University's libraries. In addition, oral histories and personal testimonies were collected from 36 individuals in the Gander Bay region. These took place between June and October 2011 and included interviews with Aboriginal fishery guardians, representatives of organisations involved in salmon conservation, provincial government departments, Aboriginal Band chiefs and their members, and employees of local municipalities and regional development organisations. Additional interviews in St John's with key informants occurred between June 2012 and April 2013.

Our paper is structured into three sections. We begin with the commercial salmon, and we trace its origins in the 1700s and its decline and eventual extinction in the early 1990s. The material that we mobilise in this section shows how 'nets' and 'rods' become juxtaposed in relation to the sustainability of Atlantic salmon. In the second section we focus on the techniques and materials of catch-and-release. Our emphasis is not on whether catch-and-release conserves salmon; we focus instead on what is cared for in the materials and techniques associated with this angling method. In the third section we draw on interviews and oral histories to reveal what we call the willful salmon. The willful salmon does not represent a third phase in the history of the salmon conservation, which we trace in the first two sections of the paper. Instead, it represents an additional way of conceptualising salmon-human entanglements that further destabilize and interfere with the dominant narrative on the conservation of Atlantic salmon in Newfoundland, and on the Gander River.

\section{Commercial salmon (1)}

Commercial salmon harvests started in Newfoundland in the early 1700s with the construction of processing facilities close to the island's numerous salmon rivers (Head, 1976). Commercial production on rivers was sustained for over a century, but there were always concerns about salmon stocks, often in response to short term or temporary collapses in salmon runs. Salmon were harvested using nets, and these were often combined with weirs that blocked off salmon rivers altogether and prevented salmon from reaching their spawning grounds to reproduce. On some of the island's narrower rivers, nets were placed from one bank to the other, and effectively acted like a weir. In the face of these intensive harvesting strategies, many smaller rivers on the island were entirely denuded of salmon stocks.

Conservation measures introduced in the late 1700s and early 1800s were aimed at opening up rivers to give salmon the opportunity to reach spawning grounds, but these measures were poorly enforced and had little impact on improving salmon production on rivers in Newfoundland. By the early 1800s the river salmon industry was in crisis and commercial harvesters shifted their attention to the bays and coastal waters around known salmon rivers, which led to a rapid rebound of salmon exports from Newfoundland. Stake nets were used just off the headlands of salmon rivers, while further out to 
sea harvesters used drift nets to catch salmon. From the 1880s, the commercial river fishery had all but ended and most salmon production came from sea based exploitation (Taylor, 1985).

The sea based salmon fishery sustained commercial exports through to the first decades of the 1900s. Indeed, export volumes from Atlantic Canada as a whole increased to a peak of $6000 \mathrm{t}$ in the 1930s. From this peak in the 1930s production levels declined steadily (Fig. 1). The reasons for the decline in production from the 1930s are complex and much debated in the scientific literature. One factor was the discovery of Atlantic salmon overwintering grounds off the coast of Greenland in the 1950s. The fish were relatively easy to harvest, and scientists estimated that $40 \%$ of these fish originated in Canadian rivers. However, the decline of salmon stocks in the nineteenth and twentieth century was also linked to the impact of industrial, mining and logging activities close to salmon rivers, which destroyed spawning habitat and prevented salmon from reproducing (Lear, 1993).

From the mid-1960s Canada's Department of Fisheries and Oceans (DFO) began an extended process of closing down the commercial salmon sector. Measures to control commercial harvests of Atlantic salmon started in the Canadian provinces of New Brunswick, Nova Scotia, and Quebec and involved licence restrictions and a voluntary licence buy-back scheme. By the 1970s, DFO announced temporary closures of industry in New Brunswick and the Gaspe region of Quebec, and harvesting was banned off the southern coast of Newfoundland. These temporary closures were subsequently made permanent from the early 1980s in New Brunswick, Nova Scotia and Quebec.

Commercial harvesting of Atlantic salmon continued on the island of Newfoundland through the 1980s, but the industry was subject to a wide range of new restrictions. These included shorter seasons, an attractive voluntary licence buy-back offer, and new regulations on net and mesh size. As a further measure to control the commercial harvesting, quotas were introduced to limit the commercial catch in Newfoundland. Despite these new controls on commercial harvests, salmon stocks in the Maritimes and in Quebec failed to recover. Much of the blame for this was directed at the Newfoundland commercial catch, which was now described as an 'interception' fishery (Lear, 1993). Salmon caught off Newfoundland's coast, experts argued, would have made it to rivers in other parts of Atlantic Canada. Efforts to rebuild stocks in the eyes of the angling

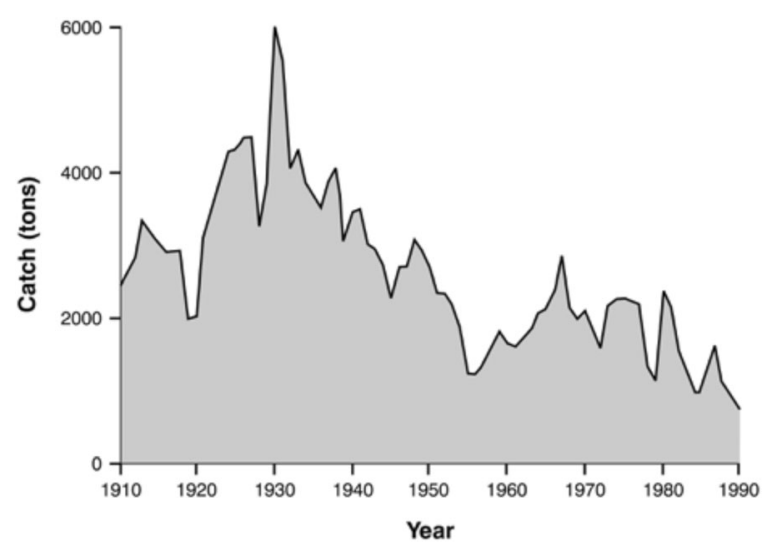

Fig. 1 Commercial production of Atlantic salmon in Canada 1910-1990. Source: Lear 1993 
community, and increasingly in the view of DFO, depended on further limits to - and ideally the closure of - the Newfoundland commercial salmon sector. By the late 1980s commercial catches in Newfoundland collapsed, prompting the decision to impose a moratorium on commercial salmon harvesting as a measure to conserve the species.

The causes for the decline in Atlantic salmon in Canada are widely recognised to be extraordinarily complex. Yet the solution to the crisis was simple: shut down commercial harvesting and ban nets. Underpinning this solution was a material politics that juxtaposed two heterogeneous networks for harvesting. The first was a network of nets, boats, processing companies, canneries, as well as poachers on salmon rivers, that became linked to salmon exploitation and resource decline. The second was a heterogeneous network of rods, reels, flies, guides, travels agents, as well as the Atlantic Salmon Federation, which became associated with salmon conservation. Attending to the materiality of salmon harvesting is crucial to understanding why, when the moratorium on commercial salmon harvesting is imposed in 1992, it involved more than the removal of licences. It also involved the banning and destruction nets.

\section{Materials - 'nets' vs 'rods'}

In the late 1940s recreational anglers in Canada established the Atlantic Salmon Association (ASA), an organisation based in Montreal aimed at articulating the views of salmon anglers in Canada. It immediately embarked on a vigorous project that involved the production of reports on the management of Atlantic salmon. The ASA 'documents' published from 1949 covered a wide range of policy and management issues relating to Atlantic salmon. Topics included government policy, the status of different fisheries across the Maritimes, and in Canada's newest province, Newfoundland and Labrador; laws and legislation; poaching; environmental threats to salmon; pollution legislation; and the science of salmon life history (e.g. ASA, 1949; Nobbs, 1949, 1952). These reports were used by members of the ASA in presentations to senior government officials in Ottawa to motivate for salmon conservation measures.

Two reports produced during this period stand out. The first was a detailed comparison of the value and expenditure of commercial salmon and angling in Atlantic Canada. The justification for the research was that while DFO had financial data on the commercial salmon fishery, there was "no information on what the sport of salmon fishing brings in for the inhabitants of the provinces concerned" (Nobbs 1949, p. 1). The ASA report drew on official DFO data and combined it with their own survey from its membership. Predictably, the results of the research provided a powerful argument for the angling community: recreational harvesters, or 'the rods' in the language of the report, caught a fraction of Atlantic salmon compared to commercial harvesters, and spent large sums on equipment and other goods and services that supported sport-fishing. The 'nets', in contrast, harvested large volumes of salmon for comparatively small returns, and spent much less on wages, equipment and other goods. Commercial harvesting also drew heavily on state resources in terms of monitoring and the administration of licences.

This report represented the first time that Atlantic salmon harvesting methods were juxtaposed in this way, and in so much detail. The 'rods' were shown to be part of a larger network made up of anglers, guides, outfitters, and lodges, and of course the Atlantic Salmon Association. The 'nets' were linked to 'netsmen', crew, handlers, 
processing workers and government inspectors. This report and the many reports that followed it comparing commercial and recreational harvesting (e.g. Grasberg, 1956; Kerswill, 1971; Tuomi, 1980) provided a detailed description of the heterogeneous networks - or the 'modes of ordering' - that shaped human salmon entanglements. Yet clearly these reports did more: they set up contrasting relationships to the Atlantic salmon resource. Anglers were not only more conservative in their 'use' of Atlantic salmon, they also generated considerably more revenue. In other words, they were economically more efficient, and they were more conservation oriented. The commercial sector was, in contrast, shown to be inefficient and wasteful. This contrast between the 'nets' and the 'rods' was laid bare by this and other analyses that were able to calculate the different value of an individual salmon in the two networks (e.g. Grasberg, 1956; Nobbs, 1949). These quantitative comparisons, which overwhelmingly favoured the angling community, added to the argument that netting was exploitative and wasteful, while angling generated large revenues, and aligned well with conservation goals.

While ASA report on 'net's and 'rods' called for a reduction in commercial salmon netting across Atlantic Canada, and a stronger role for anglers in terms of river conservation efforts, its tone was nonetheless conciliatory in making a case for a fairer share of salmon stocks for recreational anglers. The author called for new policies and approaches that would allow for a "future co-ordinated prosperity" for both 'nets' and 'rods' (Nobbs 1949, p. 2). The same conciliatory tone was absent from a second report published in the same year, which presented a far more aggressive attack on 'the nets'. The report was commissioned by the ASA and written by J.W.C. Menzies, a former Chief Inspector of Salmon Fisheries in Scotland and outspoken advocate for the conservation of Atlantic salmon (Menzies, 1951). His lengthy and detailed report provided 28 recommendations on salmon conservation, the majority of which were aimed at significantly reducing and restricting the commercial netting of salmon. Among the many recommendations focused on salmon netting, Menzies called for the closure of all drift net fisheries, limits on licencing and a ban on licence transfers, and new measures to limit net size. While he also proposed mandatory licences for anglers, there were no additional restrictions for 'the rods'. Instead, Menzies called for an extension of the angling season into autumn to allow anglers more time to fish for salmon.

Canada's DFO provided a formal - and decidedly testy - response to the Menzies report (DFO, 1952). They disagreed with his main argument about nets, and pointed out that there was no evidence that commercial gear was responsible for the decline in Canadian salmon stocks. The reported also rejected Menzies' recommendation that commercial netting should be restricted in order to conserve Atlantic salmon. Their official approach to resource management was to increase stocks by rehabilitating salmon streams to promote and facilitate salmon reproduction. Using this approach, they hoped to increase Atlantic salmon stocks so that both commercial and angling interests could share a larger and more abundant resource. In other words, regulators were unwilling to favour 'rods' over 'nets' in the name of conservation: "The aim of the fisheries scientist and administrator is to provide for the maximum long-term use of the resource - the only responsible interpretation of 'conservation"' (DFO, 1952, p. 3).

The significance of the DFO report is that it provided a clear policy statement on its approach to salmon management: it would not be drawn into choosing one resource user over another, and instead focused on increasing salmon stocks to the benefit of all 
resource users. In the late 1970s, Minister of Fisheries Romeo LeBlanc reiterated this position at an Atlantic Salmon Association conference: "A fisheries minister cannot favour angler over fishermen, or inshore fishermen versus offshore... There can be no winners in a game of power plays" (LeBlanc, 1978, p. 243). Despite LeBlanc's commitment to his Department's longstanding approach to conservation through enhancement, there were clear shifts in policy emerging during the 1970s. The decision to temporarily shut down commercial harvesting in parts of Newfoundland, New Brunswick and in Quebec in the early 1970s suggests that the idea of controlling commercial netting to conserve salmon was beginning to take hold. In the late 1970s the DFO's Atlantic Salmon Review reflected important shifts in policy, including a new commitment to managing salmon according to 'best use' in terms of economics and conservation (DFO, 1979). By this time the ASA, and its larger and more powerful successor the Atlantic Salmon Federation (ASF), had already laid the ground work for decision making through a significant number of studies that showed while commercial interests harvested around 10 times as much as anglers, the value of angling to the Atlantic Canadian economy was far greater.

The closure of commercial harvesting in Newfoundland, and the outlawing of nets, represented an important victory for recreational anglers. As Crosbie announced in his 1992 speech, it marked the end of the commercial salmon and the rebuilding of Atlantic salmon as a sustainably caught 'matchless game fish', to be enjoyed by 'future generations' of recreational anglers. The key to this shift is the juxtaposition of two sets of practices that implied different futures for Atlantic salmon. While commercial netting was shown to be synonymous with exploitation, angling became linked to sustainability and the rebuilding of endangered Atlantic salmon stocks. The 1992 announcement did not, however, mark the end of the Atlantic Salmon Federation's conservation activities: on the contrary, the ASF continued to press for new conservation measures particularly in the form of catch-and-release.

\section{Catch-and-release salmon (2)}

The moratorium on commercial harvesting (and nets) did not lead to the widely predicted rebuilding of salmon stocks in Atlantic Canada. While there were sporadic reports of a rapid rebound of salmon on several rivers in Newfoundland (e.g. Robinson, 1993), salmon runs on rivers in Newfoundland in the region as a whole remain low almost 25 years after the moratorium on commercial harvesting. The vulnerable state of Atlantic salmon stocks has strengthened the hand of the Atlantic Salmon Federation in its promotion of catch-and-release. In this section of the paper we are less concerned with why Atlantic salmon have not rebounded following the moratorium on nets, even though this is an important concern. Instead, we attend closely to the materials and methods of catch-and-release to ask how, and whether, this materially heterogeneous network that connects human and fish bodies cares for the Atlantic salmon.

\section{Lee Wulff and the origins of catch-and-release in Newfoundland}

Newfoundland has a strong connection to the origins of catch-and-release angling through Lee Wulff, widely considered to be the 'father' of fly fishing. Wulff was an American sports enthusiast, and was drawn to Newfoundland in the early decades of 
the twentieth century as angling on the island gained in popularity. Newfoundland was an attractive place to fish for salmon, and was widely advertised to Canadian and American sports fishermen, in part because most of the rivers were open to the public and not leased to private groups as was the case in Europe and other parts of North America. Wulff played an important role in publicizing salmon fishing in Newfoundland through a formal association with the Newfoundland Tourist Board starting in the late 1930s. He produced movies, and promoted the region through his own fishing exploits to an American and Canadian audience. Within the angling community, Wulff is best known for his experimentation with, and promotion of, catch-and-release methods of angling, which he argued was the key to conserving salmon stocks. In the 1960s he was proclaimed by the Atlantic Salmon Association as a "pioneer in catch-and-release fishing, believing that game fish like Atlantic salmon were too valuable and precious to be caught only once" (ASF, 2012). The Atlantic Salmon Federation continues to honour Wulff's contribution to catch-and-release, and by implication salmon conservation, through the annual 'Lee Wulff Atlantic Salmon Conservation Award'.

Wulff acknowledged that fly fishing was not the easiest method to learn, and compared to catching fish with baited hooks or setting a net across the river, it was certainly not the easiest method of retaining a salmon. Rather, as he wrote, it required "a greater delicacy of movement, more accurate timing and the coordination of both hands in casting, stripping and shooting the line" (Wulff, 1958, p. 32). 'Playing the fish' is a key component of a successful fly fishing experience. However, the purpose of playing salmon is not so much about play, as it is about playing out so that fish can be successfully landed. Playing out an Atlantic salmon using a rod and fly requires skill and patience because once a fish is hooked it can easily break the line, even when it is very tired, thus foiling the angler's efforts at landing the fish.

The rod and reel, combined with the angler's skill and patience, are designed to play out an Atlantic salmon. The reel is important because Atlantic salmon runs are "long and fast - they create a serious test for any reel... Any failure to operate perfectly usually results in the fish's escape" (Wulff, 1958, p. 55). The reel allows the angler to give line and retrieve line while playing out a salmon. But like all aspects of fly fishing it is important to maintain a balance: too much give will result in an angler having to do more work in retrieving the fish. Yet if the angler pulls in on the line too aggressively before tiring the salmon $\mathrm{s} /$ he runs the risk of snapping the line. Balancing this give and take will, over time, wear the salmon down until it can be landed (Anderson, 1985). The fishing line and the leader are also critical components of angling, and are important to playing the fish out. The leader is a much thinner extension of the weighted line and is designed to create the "illusion that an angler's fly is a swimming, floating or drifting insect, completely independent of the tackle" (Wulff, 1958, p. 64). Because mature Atlantic salmon are attracted to small bait relative to their size, the leader must be very thin to prevent the fish from seeing that the bait is tied to a line. The fly and hook are the last pieces of this technical arrangement. The main purpose of the fly is to deceive the salmon into thinking that there is some form of prey - typically an insect floating or drifting in the water, while the hook ensures the salmon's body remains attached to the line so the angler can begin playing out and reeling in his or her catch.

Once the salmon has been landed there are a series of procedures recommended for its safe release. Anderson (1985) provides four recommendations: 1) subdue the fish 
quickly, 2) do not beach the fish, 3) leave the fish in the water, and finally, 4) remove the hook carefully by twisting it gently, or if required, clip the leader, which would result in losing the hook and fly. Subduing the fish quickly is important as it prevents dangerous levels of lactic acid from building up in the salmon's system due to stress and exhaustion (Anderson, 1985). A safe release also requires that the fish remain in the water. This reduces the stress for the fish, and also ensures that the protective mucous membrane on the salmon's scales is left intact (DFO, 2012). Keeping the salmon in the water prevents pressure being exerted on its internal organs from gravity, which happens to a fish when it is removed from water (DFO, 2012). DFO's official 'angler's guide' suggests that once the angler is ready to release the salmon they should move to steady, slow flowing water and position the fish facing upstream (DFO, 2014). These techniques allow the fish to recover in a calm environment while allowing oxygen to flow over its gills to enhance recovery, and improve the chances of a successful release.

\section{Care}

The practices of catch-and-release are clearly not trivial: it requires specific materials, and it requires close attention to a range of different environmental conditions. But what does catch-and-release care for? What goods and bads are done in catch-and-release? Here we look closely at the material and methods of hooking, playing and releasing an Atlantic salmon. We explore what is cared for, and we examine a number of tensions that arise in this materially heterogenous network that claims to conserve Atlantic salmon.

Catch-and-release aims to conserve Atlantic salmon by allowing individual fish to return to the river, with the potential of producing another generation of Atlantic salmon. In this way, catch-and-release cares for both the individual fish, and the population of this fish species as a whole. For proponents of catch-and-release, the retention of an Atlantic salmon, and its subsequent death, is regarded as unnecessary and cruel. This commitment to the life of the individual salmon is reflected in the images and statements in angling magazines. As Buchanan et al. (1994, p. 56) argue, "Pictures of dead fish are becoming rare in angling magazines and when they do appear they usually draw irate letters from readers". The Atlantic Salmon Federation has proudly described young catch-and-release anglers as 'generation no kill' (Ekich, 2008, p. 23). This is a generation that has grown up with respect for the salmon, and has rejected the fatal practices of 'hook and cook' (McAdam, 2008, p. 31). The hope for this no kill generation is that "there's always a chance that you will it see again next year. If you let it go, there's always a chance" (ibid, p. 24). By releasing an individual fish, care is also assumed for the population of Atlantic salmon as a whole. This is particularly important in the case of Atlantic salmon. Unlike Pacific salmon, which die after spawning, Atlantic salmon may return from the sea to spawn in rivers more than once in their lifetime. Promoters of catch-and-release have emphasised the importance of releasing Atlantic salmon given their unique reproductive behaviour.

Catch-and-release as a practice aimed at conserving salmon and other fish species is controversial and many groups are opposed to this method of angling (for a detailed review see Arlinghaus et al. 2007). While we acknowledge these positions, we focus here on a number of tensions arising from the materials and methods associated with the catch-and-release salmon. The first is that although care is presumed for individual salmon bodies, they are nonetheless expected to endure the stress and trials of an angling 
event, and ideally on more than one occasion. Wulff's famous statement is that 'a good game fish is too valuable to be caught only once'. What this suggests of catch-andrelease practice is that care of the aggregate salmon species is more important than the care of a single salmon body that must endure the stress and trial of one or more angling encounters. In other words, care in catch-and-release is largely reserved for the Atlantic salmon species, rather than individual salmon that must endure one or more experiences of being 'played out'.

The second tension with catch-and-release is related to 'playing out' and the careful balance required in landing and releasing salmon. The fish must be played for long enough so that it can be landed without breaking the line. But it should not be 'over-played', which could potentially damage its organs and reduce the likelihood of the fish surviving after being released back to the river. The materials and methods of fly fishing, however, favour 'over-playing' rather than just 'playing out'. ${ }^{1}$ For instance, the leader must be thin as possible otherwise the likelihood of a salmon taking a fly is much reduced. Given this situation, anglers are more likely to extend the play so that they do not lose the hooked fish. The situation is particularly relevant to Atlantic salmon: our research participants pointed out that the Atlantic salmon is a very powerful fish and landing it requires more play than might otherwise be the case. There is an additional variable. In fly-fishing the challenge is to use the lightest possible gear: this includes lighter lines that have low breaking strain relative to the size of the fish being caught, and rods that are also designed for smaller fish relative to what is typically caught. For anglers such as Lee Wulff and his many followers, having lighter gear relative to the size of the fish represented the 'ultimate challenge' in fly fishing (cited in Hustins, 2010, 155). Of course, succeeding in this challenge requires more time to play out the fish, presumably with a greater risk that the fish is too exhausted and stressed to survive a return to the river.

The third tension has to do with the conditions that will lead to a successful catch-andrelease. We noted earlier that for salmon to recover from the ordeal of being hooked and played, they should be placed in a slow flowing stream. However, this requirement clashes with other materials on rivers like the Gander, including the Gander River boat. The Gander River boat is an iconic feature of the river that has been integral to salmon fishing for many decades. The river boats are one of the first things one sees when driving across the river and Gander Bay at the mouth of the river. Our research participants in Gander Bay and Glenwood told us that these boats 'lie impatiently', as avid river users and salmon anglers await the opening of salmon fishing. The river boats are particularly important from an angling perspective because they allow anglers to reach sections of the river that are otherwise unreachable from the river bank.

While the Gander River boat is a key element of the river, it clashes with the practices associated with catch-and-release. Our research participants explained to us that releasing a hooked salmon safely cannot be easily achieved from a river boat:

And they [catch-and-release proponents] tell you that you have to take it to still water, well if you are out there fishing on the current, it will almost drag your anchor. Then you've got to go 300-400 yards back up to the pond. How are you going to manage a boat and handle your rod? You see, this is where experience comes into it. It might look nice on paper, but it doesn't make sense (Interviews, Gander Bay). 
Catch-and-release practice assumes that the angler is in the stream, possibly wearing waders, and that they have easy access to a slow flowing stream. As our research participant noted, these conditions are hard to meet, particularly if the angler is on a boat. The difficulty of achieving all of the conditions for a successful catch-and-release, combined with the stress of being hooked and landed, has fuelled speculation in the local media and in scientific circles that many Atlantic salmon that are caught and released subsequently die.

A flag that is associated with the Atlantic Salmon Federation provides a useful illustration of the final tension in catch-and-release. The flag has an Atlantic salmon that is the process of being released. Two large arrows that are commonly used to indicate the practice of recycling surround this image. Catch-and-release, then, recycles individual salmon for one or more human salmon entanglements so that the species as a whole can continue to flourish. In this way, the arrows that surround the salmon being released connect in significant ways to contemporary discourses on recycling as a practice that improves environmental sustainability. Recycling as a concept and practice has, however, come under scrutiny through the work of David Graeber (2012). He shows that the term 'recycle' first appeared in English in the mid-1920s and was used as a specific term to describe a technical process in oil refining and other industrial processes. Over the course of the last 50 years, recycling has shifted to become a sociomaterial practice carried out mostly by individual consumers and households for environmental goals. The moral imperative to recycle, Graeber (2012, p. 281) writes, is remarkable given "the fact that consumers produce only a tiny proportion of the world's waste". Yet the effect is clear: it is individuals that should be responsible for protecting the environment, and in the case of Atlantic salmon, its future sustainability.

The tensions we identified in catch-and-release, and the moral imperative on individuals to sustain Atlantic salmon stocks, stand in stark contrast to our third salmon real, the willful salmon. The willful salmon does not represent a new or discreet phase in the history salmon conservation. Instead, it is a fish that emerged through oral histories and testimonies with people on the Gander River. As we explore below, the significance of this salmon is the way it is cared for in human-salmon entanglements.

\section{Willful Salmon (3)}

The willful salmon became visible to us during first author's fieldwork in Glenwood and Gander Bay. Recognizing this fish was a gradual process. This is not a fish that we would have encountered by pouring over archival materials, policy documents, or by speaking to those directly involved in salmon conservation. The willful salmon is, like the commercial salmon and the catch-and-release salmon, born out of relational specificity that is historically produced, dynamic and materially heterogeneous. The practices associated with this salmon are often hidden, and rarely acknowledged. By naming the willful fish as an ontologically legitimate entity we help level the playing field in which resource politics have played out and continue to play out on Newfoundland salmon rivers, and specifically the Gander River.

In the context of current federal regulations governing salmon fishing, the willful salmon can be enacted using similar materials as the catch-and-release salmon. These include a fishing rod, salmon-grade lines and leaders, hooks, lures, and landing nets. The willful fish can also be caught with nets and using rods and live bait, although these are 
activities that are prohibited by law and strictly enforced in Newfoundland. The critical moment in performing the willful salmon is that during a successful fishing encounter, the willful salmon is killed. In other words, it is the act of killing and then consuming an Atlantic salmon that separates the catch-and-release and willful salmon.

\section{The salmon is food}

When the willful salmon is enacted, it is an individual fish that is caught and subsequently eaten. Across Newfoundland and on the Gander River, the practice of netting a few salmon has provided physical nourishment and a sense of cultural continuity for many years. As one of our research participants told us:

Growing up here - you lived off the land - if you wanted a salmon, even though it was illegal in the eyes of people, you'd always go down to the brook and get a feed of salmon. And you didn't do it so you would take all of the fish, but you would go get a meal of salmon for yourself. Or get a moose. You take what you needed. It wasn't taken to sell or barter or anything like that. You'd take it for your own consumption. (Interviews, Gander Bay).

Here, the salmon bodies provide the material substance for human bodies to sustain themselves physically, although ' $a$ feed' itself has connotations beyond the seemingly banal act of ingesting food. In practice, the salmon caught on the Gander River is subsequently taken home, cleaned, cooked and shared with family and friends, who participate together in eating this meal, or in the local expression, 'having a feed'. The act of catching and eating salmon has been an important tradition among Mi'kmaq and nonAboriginal people along the Gander River for generations. Salmon has fed people since they first started to trek into the interior of the island and then later set up settlement in Glenwood. And while a formally established Aboriginal Food Fishery has never existed, this has not stopped people (Mi'kmaq or non-Aboriginal) from eating salmon for their own consumption. As described in one interview: "More recently I heard people express 'oh well, there was never a food fishery', but people as long as people have been living on the Gander River, they could always collect a feed of salmon on the river" (Interviews, Gander Bay).

Eating, despite being an entirely ordinary act, is quite a profound act as far as intimacy and responsibility are concerned. Regardless of the human companionship around the table - eating and ingesting are acts that are entirely dependent on the presence of others (Haraway, 2008; Mol, 2008; Stratern, 2012). When Mol (2008, p. 30) works through the subjectivities of eating, she asks if "I eat an apple....is the agency in the $I$ or in the apple? I eat, for sure, but without apples before long there would be no "I" left". There is a kind of transubstantiation that occurs in eating, where on a material level one is literally composed of the apple, and the apple becomes a part of the self. This suggests that as agents, we are not solitary at all, but rather completely interdependent on the agency of non-human others (e.g. Strathern 2012), be that plant or animal. For Haraway (2008, p. 294-5) "no community [in the broadest sense] works without food, without eating together. This is not a moral point, but a factual, semiotic and material one that has consequences... Driven by [the desire for a 'pure diet'] a diner's only permitted food would be oneself, ingesting, digesting and gestating the same without end". 
In the case of the willful salmon, it is intimately linked to the angler, fishing person, and all those who partake in eating it.

The salmon plays a fundamental role in this multifaceted experience of being nourished - as 'individuals' but also for the larger cultural traditions which exist on the river (e.g. Taylor, 2009). An Atlantic salmon heading upstream has likely travelled great lengths to return to the same spawning ground and it makes such a tremendous effort to do so, and for this reason, the salmon is revered by those who get a chance to catch it, or even catch a glimpse of it flicker through the air. The angler and the salmon share an intimacy as the angler struggles to land the fish, eventually killing the salmon once it has been reeled in within reach. This intimacy and responsibility reveals a second quality of the willful salmon: it is killed because its will is taken into account.

\section{The salmon has will}

Demonstrating good care is very specific and immediate to the practices that enact a particular reality (Mol, 2008). This is the case with the willful salmon. Haraway (2008) suggests that good care, or any good for that matter, cannot be preordained or assessed from a position outside of the enactment itself. The human-salmon encounter, particularly the practices which make up the willful salmon provide a stark example: for who is more familiar, more intimately tied to this interaction than the particular salmon and equally particular human facing each other at either end of the fishing line? Following Haraway, the salmon and the angler are companion species that evoke response-ability through their encounter, which fundamentally brings them into being. Response-ability, Haraway (2010, p. 4) states is a process where "becoming-with, not becoming, is the name of the game... Ontologically heterogeneous partners become who and what they are in relational material-semiotic worlding". Becoming-with does not necessarily entail a specified action, rather it unfolds through encounter, which- like the performances described in this paper - brings about a particular reality. Here, not only is the willful salmon enacted, but so too is the angler as neither exists independent of their shared interaction.

Response-ability is performed on the Gander River as a lure (and hook) stirs a passing salmon's interest, to the point that she (the salmon ${ }^{2}$ ) engages and the battle of wills begins. This battle of wills is pronounced, from both ends of the line, and the angler may be equipped with the correct gear and technical knowledge, but as stated by one angler "for its size I'd say [the salmon] is the strongest fish in the water because there's no man [sic] that can hold a salmon if he wants to get away" (Interviews, Gander Bay). The play can go one of two ways: the salmon will escape, either by struggling free from the hook or it will snap the thin leader attached to the hook. Alternatively, the salmon will tire of the play. She will be played out. At this point, and only at this point, she will resign herself to the struggle, ceasing to fight any longer as the angler finally pulls her in to land. This is a willful salmon, and because her will has been undeniably broken, the angler will land and kill her as quickly as possible. Good care in this situation is not necessarily attractive because it does involve the salmon being killed, but good care often offers little in the way of attractiveness (Mol, 2008). As one of our research participants noted,

by the time you can get that salmon and pull it alongside to take the hook out of it, there's not too much life left in him, being sloughed and being beaten around, that takes the good out of it. (Interviews, Gander Bay) 
The salmon has been destroyed, not merely in physical sense, such a fish becoming placid, or after being gutted, demonstrating a tell-tale sign of having undergone severe distress with a burst gallbladder, which leaves remnant yellow fluid (Interviews, Gander Bay). But the salmon, who has faced the angler at the other end of the line and struggled mightily, concedes defeat by abandoning the will to fight. At the moment the willful salmon is landed, the option to release it back to the river cannot be considered. Physically and emotionally, the salmon has been worn down and worn out. For the angler in the willful salmon enactment killing is kindness. At this moment, the best thing for the particular salmon's well-being is to end its struggle, but also to acknowledge that the salmon has in fact given her everything to this struggle.

The demands that are made on the angler and the salmon are reciprocating. They each struggle for victory - where success is marked by very different ends no less - but when the struggle is over in favour of the angler, then clear concessions are made. In this way, we argue the willful salmon is cared for and done well on the Gander River. Living together, between the angler and the salmon on the Gander River, entails death for the salmon. The question then becomes how to go about this relationship respectfully and carefully. Of course, the answer is not absolute; rather, it requires the continued commitment on the part of the angler (and salmon) in working through the best ways for living and dying to occur - and accepting the consequences of these practices.

\section{Conclusion}

This paper has examined the material politics of salmon conservation. Our approach has been to focus on the materials and practices that connect human and salmon bodies; in other words, the material orderings that shape the human salmon encounter in Newfoundland and on the Gander River. Attending to these heterogeneous practices has allowed us to identify three salmon: the commercial salmon, the catch-and-release salmon and the willful salmon. In the dominant narrative for conservation, the catchand-release salmon is at the centre of salmon sustainability, and is juxtaposed against commercial harvesting using nets where the salmon being killed and eaten. Our third salmon, the willful salmon, is a product of a specific socio-material network and it too is killed and then eaten in a human salmon encounter. By shifting the register, and by asking the question - what is cared for in these different modes of ordering? - we have been able to interfere with the dominant narrative for salmon conservation. In particular, we have identified tensions in what is cared for in catch-and-release, and we present different forms of care through the willful salmon. The juxtaposition of these two fish provides a sharp and uncomfortable challenge to the dominant discourse of Atlantic salmon conservation in Newfoundland.

By challenging the dominant discourse of salmon conservation, we are attempting to think through, and contribute to, the 'companion species worldliness' that is so central to Haraway's project on multi-species responsibility. In the case of Atlantic salmon, this is not an easy task given the rationality and reason that support catch-and-release. What could be more obvious than the argument that a hooked salmon should be released so that it can continue to live and hopefully reproduce? And that this is more 'sustainable' than practices that kill and consume salmon? Yet, this is precisely the kind of closure in the face of reason and calculation that Haraway (2008, p. 71) asks us to confront: they are the kind practices, she writes, that "will never take us into that kind 
of open where multi-species responsibility is at stake". In our case, we are indebted to the willful salmon, and to our research participants who told us about this fish. It is the willful salmon that provides an opening to multi-species responsibility for Atlantic salmon in Newfoundland. The willful salmon forces us to acknowledge and respond to the ordeal that comes when humans and salmon meet through a hook and line, or through a net. It helps us interfere with the idea that an Atlantic salmon should be too valuable to be caught only once. And it helps us come to terms with killing in a way that is responsible to the fish that will later be eaten.

\section{Endnotes}

${ }^{1}$ For Indigenous groups in North America and parts of Europe, fish should not be 'played with' under any circumstances. In Alaska, Fienup-Riordan (1994) has traced the conflict between Indigenous groups and recreational fishers, while Nadasdy $(2003,2007)$ examines similar conflicts in the Yukon. In both contexts catch-and-release is considered 'senseless abuse' (Fienup-Riordan, 1994, 184) and is a practice that fails to respect the fish who gives up its life for food consumed by humans.

${ }^{2}$ We have intentionally used the female pronoun as a way of interfering with the oft cited description of salmon as the 'king' of the river.

\section{Acknowledgements}

Thanks to Jahn Petter Johnsen, Signe Sonvisen and Aarthi Sridar for comments on an earlier draft of this paper. We are especially grateful to two anonymous referees for their generous and thoughtful comments on this paper. Although we were not able to address all of their comments in this revised version, their insightful suggestions will help us to keep us thinking about Atlantic salmon for a long time to come.

\section{Funding}

This research received no funding.

\section{Authors' contributions}

The authors contributed equally to the research and writing of the manuscript. Both authors read and approved the final manuscript.

\section{Authors' information}

Jennifer Daniels completed her graduate degree at Memorial University and is currently a freelance researcher. Charles Mather is a professor in Geography at Memorial University. This paper represents our on-going work on the politics of Atlantic salmon conservation in Newfoundland.

Competing interests

The authors declare that they have no competing interests.

\section{Publisher's Note}

Springer Nature remains neutral with regard to jurisdictional claims in published maps and institutional affiliations.

Received: 18 January 2017 Accepted: 30 August 2017

Published online: 08 November 2017

\section{References}

Anderson, G. 1985. Atlantic salmon and the fly fisherman. Montreal: Salar Publishing.

Arlinghaus, R., S.J. Cooke, J. Lyman, D. Policansky, A. Schwab, C. Suski, S.G. Sutton, and E.B. Thorstad. 2007.

Understanding the complexity of catch-and-release in recreational fishing: An integrative synthesis of global knowledge from historical, ethical, social and biological perspectives. Reviews in Fisheries Science 15 (1-2): 75-106.

ASA. 1949. The protective services for salmon in the eastern provinces of Canada, document no, 16. Montreal: Atlantic Salmon Association.

ASF. 2012. Science and best practices of live release. Montreal: Atlantic Salmon Association Retrieved from http://asf.ca/ science-and-best-pracitices-of-live-release.html.

Bear, C., and S. Eden. 2011. Thinking like a fish?' Engaging with nonhuman difference through recreational angling Environment and Planning D 29: 336-352.

Buchanan, R.A., T.A. Pinfold, L.S. Carter, J. Baird, and J. Christian. 1994. Strategy for the development of recreational fisheries in Newfoundland and Labrador. Government of Newfoundland and Labrador: St John's. 
Crosbie, J. 1992. Statement by the Honourable John C. Crosbie, minister of fisheries and oceans on CanadaNewfoundland Atlantic Salmon initiatives. Ottawa: Department of Fisheries and Oceans.

de la Bellacasa, M.P. 2011. Matters of care in technoscience: Assembling neglected things. Social Studies of Science 41 (1): $85-106$. de la Bellacasa, M.P. 2012. Nothing comes without its world': Thinking with care. The Sociological Review 60 (2): 197-216. de la Bellacasa, M.P. 2015. Making time for soil: Technoscientific futurity and the pace of care. Social Studies of Science 45 (5): $691-716$

DFO. (1952). Comments on "A report on the present position of the Atlantic salmon fisheries of Canada with recommendations for their regulation and improvement" Ottawa: Department of Fisheries and Oceans.

DFO. 1979. Atlantic Salmon review: Task force for the review. Ottawa: Department of Fisheries and Oceans.

DFO. (2012). Temperature threshold to define management strategies for Atlantic salmon (Salmo salar) fisheries under environmentally stressful conditions. Canadian Science Advisory Secretariat Science Advisory Report 2012/019. Retrieved from http://waves-vagues.dfo-mpo.gc.ca/Library/346488.pdf.

DFO. 2014. Catch-and-release. Anglers Guide 2014-2015. Ottawa: Department of Fisheries and Oceans.

Ekich, F. 2008. Generation no kill, 23-25. Winter: Atlantic Salmon Journal.

Fienup-Riordan, A. 1994. Eskimo essays: Yup'lk Lives and how we see them. New Brunswick, New Jersey: Rutgers University Press.

Ginn, F., U. Beisel, and M. Barua. 2014. Flourishing with awkward creatures: Togetherness, vulnerability, killing'. Environmental. Humanities 4: 113-123.

Graeber, D. 2012. Afterword: The apocalypse of objects - degradation, redemption and transcendence in the world of consumer goods. In Economies of recycling: The global transformation of materials, values and social relations, ed. C. Alexander and J. Reno, 277-289. London: Zed Books.

Grasberg, E. 1956. Economic benefits of the Atlantic salmon to the province of New Brunswick, Department of Economics and Political Science. Fredericton: University of New Brunswick.

Haraway, D. 2008. When Species Meet. Minneapolis: University of Minnesota Press.

Haraway, D. 2010. When species meet: Staying with the trouble. Environment and Planning D: Society and Space 28 (1): $53-55$

Head, C.G. 1976. Eighteenth century Newfoundland: A geographer's perspective. Ottawa: Carleton Library.

Hustins, D. 2010. Rivers of dreams: The evolution of fly-fishing and conservation of Atlantic salmon in Newfoundland and Labrador (1700-1949). Tight Lines: St. John's.

Kerswill, C.J. 1971. Relative rates of utilization by commercial and sport fisheries of Atlantic salmon from the Miramichi River, New Brunswick. Journal of the Fisheries Research Board of Canada 28: 351-363.

Keul, A. 2013. Embodied encounters between humans and gators. Social \& Cultural Geography 14 (8): 930-953.

Law, J., and M.E. Lien. 2012. Slippery: Field notes in empirical ontology. Social Studies of Science 43 (3): 363-378.

Law, J., and A. Mol. 2011. Veterinary realities: What is foot and mouth disease? Sociologia Ruralis 51 (1): 1-16.

Law, J., and V. Singleton. 2014. ANT, multiplicity and policy. Critical. policy studies 8 (4): 379-396.

Lear, W.H. 1993. The management of Canadian Atlantic salmon fisheries. In Perspectives on Canadian marine fisheries management, ed. L.S. Parsons and W.H. Lear, 151-176. Ottawa, NRC research press.

LeBlanc, R. 1978. Closing address. In Atlantic Salmon: it's Future, the proceedings of the second international Atlantic Salmon symposium, fishing new books, ed. A.E.J. Went, 234-246. Farnham.

Lien, M.L. 2015. Becoming Salmon: Aquaculture and the domestication of a fish. Irvine: University of California Press.

Lien, M.L., and J. Law. 2011. Emergent aliens': On salmon, nature and their enactment. Ethnos 76 (1): 65-87.

Lorimer, J. 2006. What about the nematodes? Taxonomic partialities in the scope of UK biodiversity conservation. Social \& Cultural Geography 7 (4): 539-558.

Martin, A., N. Myers, and A. Viseu. 2015. The politics of care in technoscience. Social Studies of Science 45 (5): 625-641.

McAdam, M. 2008. Winds of change, 28-31. Summer: Atlantic Salmon Journal.

Menzies, W.J.M. 1951. A report on the present position of the Atlantic salmon fisheries of Canada: With recommendations for their regulation and improvement. Montreal: Atlantic Salmon Association.

Mol, A. 2008. I eat an apple: On theorizing subjectivities. Subjectivity 22: 28-37.

Nadasdy, P. 2003. Hunters and bureaucrats: Power, Kowledge, and aboriginal-state relations in the Southwest Yukon. Vancouver: UBC Press.

Nadasdy, P. 2007. The gift in the animal: The ontology of hunting and human-animal sociality. American Ethnologist 34 (1): $25-43$.

Nobbs, P.E., 1949. Expenditures by rods and earnings by nets in eastern Canada, document no. 14. Montreal: The Atlantic Salmon Association.

Nobbs, P.E. 1952. The management of salmon rivers in eastern Canada. Montreal: The Atlantic Salmon Association.

Parenteau, B. 1998. Care, control and supervision': Native people in the Canadian Atlantic Salmon fishery, 1867-1900. The Canadian Historical Review 79 (1): 1-14

Parenteau, B. 2004. A very determined opposition to the law': Conservation, angling leases, and social conflict in the Canadian Atlantic salmon fishery, 1867-1914. Environmental History: 436-463.

Robinson, J.B. 1993. Welcome back! Field \& Stream, December, 55-60.

Strathern, M. 2012. Eating (and feeding). Cambridge Anthropology 30 (2): 1-14.

Swanson, H.A. 2015. Shadow ecologies of conservation: Co-production of salmon landscapes in Hokkaido, Japan and southern Chile. Geoforum 51: 101-110.

Taylor, J. 2009. Making salmon: An environmental history of the northwest fisheries crisis. Seattle: University of Washington Press.

Taylor, V.R., 1985. The early Atlantic Salmon fishery in Newfoundland and Labrador. Canadian special publications of fisheries and aquatic sciences, no. 76. Ottawa: Department of Fisheries and Oceans.

Tuomi, A.L.W. 1980. Canada's Atlantic salmon: An economic evaluation of the New Brunswick salmon sports fishery, special publication series no. 8. New York: The International Atlantic Salmon Foundation.

Wulff, L. 1958. The Atlantic salmon. New York: A.S. Barnes. 